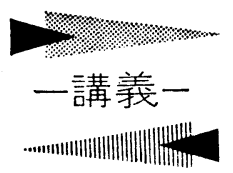

$$
\text { 13. ロランCシステム }
$$

ロランCシステムはロランAをより精度よく, かつ， 広い地域で利用できるよう改良したシステムで, 本来軍 用であるが，民間にも開放され利用可能である. 現在, 世界に表 4 に示す 8 組のチェーンがあり，1チェーンは 3 ～局構成であるが，そのすべてをアメリカが運用し ている. ロランCをその本来の性能を発揮するよう利用

表4 ロ ラ ン C 送信 ${ }^{8)}$

\begin{tabular}{|c|c|c|c|c|c|}
\hline チ× -ン名 & 繰返儿周期 & 主従局 & 局 & 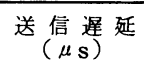 & $\begin{array}{l}\text { 送信出力 } \\
(\mathrm{kW})\end{array}$ \\
\hline アメリカ東海岸 & SS7 & $\begin{array}{l}\mathrm{M} \\
\mathrm{W} \\
\mathrm{X} \\
\mathrm{Y} \\
\mathrm{Z}\end{array}$ & $\begin{array}{l}\text { Carol ina Beach, N.C. } \\
\text { Jupiter, Fla } \\
\text { Cape Race, Newfoundland } \\
\text { Nantucket Is, Mass } \\
\text { Dana, Ind. }\end{array}$ & $\begin{array}{l}13,695.48 \\
36.389 .56 \\
54,541.27 \\
68,560.68\end{array}$ & $\begin{array}{r}1,000 \\
400 \\
2,500 \\
400 \\
400\end{array}$ \\
\hline 地 中 海 & $\mathrm{SL}_{1}$ & $\begin{array}{l}\mathrm{M} \\
\mathrm{X} \\
\mathrm{Y} \\
\mathrm{Z}\end{array}$ & $\begin{array}{l}\text { Simeri Crichi, Italy } \\
\text { Lampedusa, I taly } \\
\text { Targabarun, Turkey } \\
\text { Estartit, Spain }\end{array}$ & $\begin{array}{l}12,757.12 \\
32,273.28 \\
50,999.68\end{array}$ & $\begin{array}{l}300 \\
400 \\
300 \\
400\end{array}$ \\
\hline ノールウェイ岸 & $\mathrm{SL} 3$ & $\begin{array}{l}\mathrm{M} \\
\mathrm{W} \\
\mathrm{X} \\
\mathrm{Y} \\
\mathrm{Z}\end{array}$ & $\begin{array}{l}\text { Ejde, Faroe Is. } \\
\text { Sylt, Germany } \\
\text { Bo. Norway } \\
\text { Sandur, Iceland } \\
\text { Jan Mayen, Norway }\end{array}$ & $\begin{array}{l}30,065.69 \\
15,048.16 \\
48,944.47 \\
63,216.20\end{array}$ & $\begin{array}{r}400 \\
400 \\
300 \\
1,500 \\
300\end{array}$ \\
\hline 北 大 西 洋 & SL 7 & $\begin{array}{l}\mathrm{M} \\
\mathrm{W} \\
\mathrm{X} \\
\mathrm{Z}\end{array}$ & $\begin{array}{l}\text { Angis soq, Greenland } \\
\text { Sandur, Island } \\
\text { Ejde, Faroe Is. } \\
\text { Cape Race, Newfoundland }\end{array}$ & $\begin{array}{l}15,068.10 \\
27,803.80 \\
48,212.80\end{array}$ & $\begin{array}{r}500 \\
1,500 \\
400 \\
2,500\end{array}$ \\
\hline 北 太平洋 & SH 7 & $\begin{array}{l}\mathrm{M} \\
\mathrm{X} \\
\mathrm{Y} \\
\mathrm{Z}\end{array}$ & $\begin{array}{l}\text { St. Paul, Pribiloff Is. } \\
\text { At tu, Alaska } \\
\text { Port Clarence, Alaska } \\
\text { Sitkinak, Alaska }\end{array}$ & $\begin{array}{l}14,875.30 \\
31,069.07 \\
45,284.39\end{array}$ & $\begin{array}{r}400 \\
400 \\
1,800 \\
400\end{array}$ \\
\hline 中部太平洋 & S 1 & $\begin{array}{l}\mathrm{M} \\
\mathrm{X} \\
\mathrm{Y}\end{array}$ & $\begin{array}{l}\text { J ohnston Is } \\
\text { Upolo Pt., Hawaii } \\
\text { Kure, Midway Is. }\end{array}$ & $\begin{array}{l}15,972.44 \\
34,253.02\end{array}$ & $\begin{array}{l}400 \\
400 \\
400\end{array}$ \\
\hline 北西太平洋 & S S 3 & $\begin{array}{l}\mathrm{M} \\
\mathrm{W} \\
\mathrm{X} \\
\mathrm{Y} \\
\mathrm{Z}\end{array}$ & $\begin{array}{l}\text { 硫黄鳥, Bonin Is. } \\
\text { Marcus Is. } \\
\text { 北海道 } \\
\text { 慶佐次, 沖縄 } \\
\text { Yap, Caroline Is. }\end{array}$ & $\begin{array}{l}15.283 .94 \\
36,684.70 \\
59,463.34 \\
80,746.78\end{array}$ & $\begin{array}{r}3,000 \\
3,000 \\
400 \\
400 \\
3,000\end{array}$ \\
\hline 東南アジフ & $\mathrm{SH} 3$ & $\begin{array}{l}\mathrm{M} \\
\mathrm{X} \\
\mathrm{Y} \\
\mathrm{Z}\end{array}$ & $\begin{array}{l}\text { Sat tahip, Thailand } \\
\text { Lampang, Thailand } \\
\text { Con Son, South Vietnam } \\
\text { Tan My, South Vietnam }\end{array}$ & $\begin{array}{l}13,182.87 \\
29,522.16 \\
43,807.30\end{array}$ & $\begin{array}{l}400 \\
400 \\
400 \\
400\end{array}$ \\
\hline
\end{tabular}

* 原稿受付 昭和 48 年 10 月 4 日

** 正会員運輸省奄子航法研究所 (三䳡市新川 6-38-1)

するには相当に高級な受信機が必要で, 現在, 普通に使 用されているロラン $\mathrm{A} / \mathrm{C}$ 受信機では必ずしもロラン $\mathrm{C}$ を十分に活用することにはならない. しかし，最近はわ が国でも本格的な受信機が一，二製造されるようになっ てきいる.

ロランCは，すべての局が $100 \mathrm{kHz}$ の搬送波のパルス 電波を使用しているが，そのパルスの形で受信点へ電波 の到来時間差の測定を行なうとともに, そのパルスの中 
に含まれている搬送波の位相比較による時間差測定を併 用している．これはパルス（のエンベロープ）で粗の時 間差測定と位相差の測定による精測定をあわせ行なうこ とを意味し，また，位相差の測定によるアンビギティは パルスェンベロープの測定で取除くことができるのであ る、ロランCの送信電波のパルス波形は図 15に示す形で, その送信のエネルギの大半 (99\%)は90〜110 kHzの中に はいるよう考慮されている。そして, 位相差の測定は立 上がりから 3 サイクル目で行なうことになっているが， これは， $100 \mathrm{kHz}$ 波も電離層反射による空間波があり， 遅延時間を考えるとその 1 -Hop-E が 4 サイクル目以下 に混合してくることになるので, それによる位相の干涉 を防ぐためである。なお, 位相差の測定は普通の場合前 述のように $1 / 100$ サイクル程度までは可能であるので, ロランCの場合 $100 \mathrm{kHz}$ の 1 サイクルは $10 \mu \mathrm{s}$ であるか ら $0.1 \mu \mathrm{s}$ までの時間差測定が可能で, ロランAに比して 1 桁測定精度の向上ができる.

ロランCでは, 送信パルスは 1 個でなく, $1,000 \mu \mathrm{s}$ ごとの 8 個（主局のみは識別のため 9 個 )のパルスを連 続して送信している．これは，多くのパルスでの測定の 平均值をとることによって測定精度の向上をさせるため でこれによって送信の尖頭電力が低減できる結果とな っている。1 チェーンは, 主局, 従局 (W, X, Y, Z と 名付ける) の順で続けて送信を行ない, 各局の送信の間 には定まった十分の時間間隔を置いてあるので, 受信点 ではこの順番が入れかわることはない，その模様を主局 1 , 従局 2 の場合について図 16 に示す.

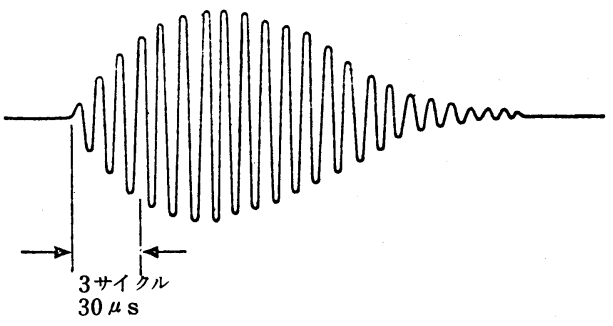

図 15 ロランC電波の送信波形

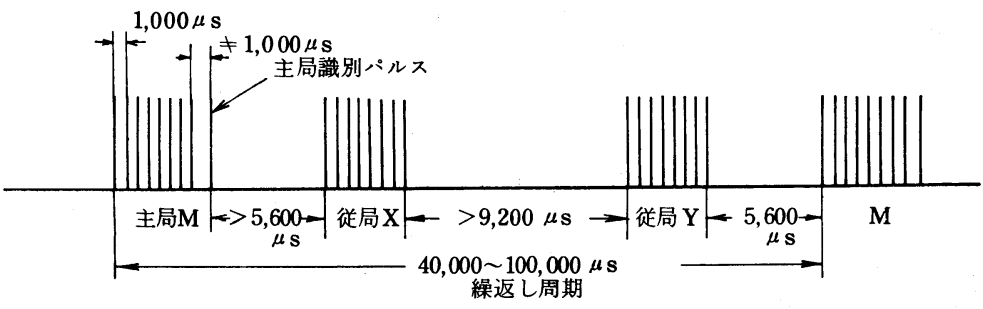

主 局

12234566789912345678

第 1 周期 ++--+-+-++++++--+

第 2 周期 +--+++++-+-+-++--
まず，ロランCのパルスの繰返し数（周期 ) であるが， それはロラン $\mathrm{A} の \mathrm{~S}, \mathrm{~L}, \mathrm{H}$ の各八つの周期 (表 3 (b)の カッコ内) に加えて, S S $(100,000 \mu \mathrm{s}), \mathrm{SL}(80,000)$, $\mathrm{SH}(60,000) の$ 三つの基本繰返し周期があり, 表 3 同様 それらには $0 \sim 7$ の特殊続返し周期をもち，48種類の繰 返し数があるが，実際に使用されているのは表 4 のとお りである. 各従局は主局の信号を受信後それぞれの局に 割当てられた遅延時間を経てから送信を行なっており， その主局の送信に対する従局の送信時間の遅れ( $D \mu \mathrm{s})$ は表 4 の第 5 欄に示すとおりで, 例えば, S S 3 の， X局, すなわち, 北海道 (十勝太 ) 局では硫黄島の主局との間 の伝搬時間 $\beta=6,684.70$ で局での遅延が $30,000 \mu \mathrm{s}$ とな って， $D=36,684.70 \mu \mathrm{s}$ というとになる．また，主局 の送信は世界標準時のUTC (協定世界時)に同期してい るが，繰返し周期の関係上，例えば， SS3 チェーンでは 997周期ごとにその送信の立上がりが正しい秒の開始と 一致する.

ロランCの送信のもう一つの特徵は位相符号化である. 図 15 の第 1 サイクル目のはじめの振れが正の位相（図で 上へ）振れるのが十，反対に負（下）のほうに振れるの をーとすると図 16 の下段に示すように主従局の各パルス について各繰返しの第 1 のサイクルと第 2 のサクルで それぞれ定められた符号づけをして送信を行なっている. この目的はロランC用の受信機が本来自動動作をするた め, 主局と従局との判別, 主局パルスの捜索, 自動周期, 主従 8 本のパルスの誤整合防止などに使用するためであ る.

ロランCの位置の線の值を表わす受信時間差 $T$ の值は 以上の記述から，

$T=$ 主従局の受信時間差 $-D$ (表 4 )

で求められ，この $T$ の値がそのまま口ラン海図の位置の 線あるいは口ラン表に示されており，（4）式同様計算 が可能である.

ロランC用の受信機で現在広く使用されているのはロラ ンAとの兼用の受信装置で, その動作も操作方法も口ラ ンAとほぼ同じで，ロランAと同様のパルスの重ね合わ 
せのあとにもう一段階スコープによる搬送波の位相の重 ね合わせの操作が加わる. これらの場合, 使用パルスは 8 本のうちの最初の 1 本のみであるので, 前述したよう な多パルスによる平均をとる操作ができず，また，口ラ ンCの本来の使用方法である自動処理も行なわない形で ある. 前述のように最近，わが国でも一，二本格的な自 動口ランC 受信機も入手可能になってきたので，受信機 の選定に当っては十分その内容を確かめる必要があろう.

ロランCの $100 \mathrm{kHz}$ 波は, ロランAの $2 \mathrm{MHz}$ 波と異な り, 電離層の $\mathrm{E}$ 層に達する前により低い高度にある $\mathrm{D}$ 層 で反射されてしまう。図 17 は大略の電界強度值を示す もので, ロランAに比しはるか遠距離（もちろん送信電 力 (表4)によっても異なるが， 1,000 海里以上の距離) までを覆域とできる. それより更に遠距離になると 1 Hopの空間波が使えることになるが，地表波と空間波の 分離ができないので，この場合は地表波が十分减衰して 空間波の位相性に全く影響を与えていないことを確認す る必要がある．D層による空間波の伝搬遅延時間は $\mathrm{E}$ 層 でのそれよりも安定であり，図18にD層の高さと遅延時 間との関係を示す．普通は電離層の高さを昼間は $73 \mathrm{~km}$,

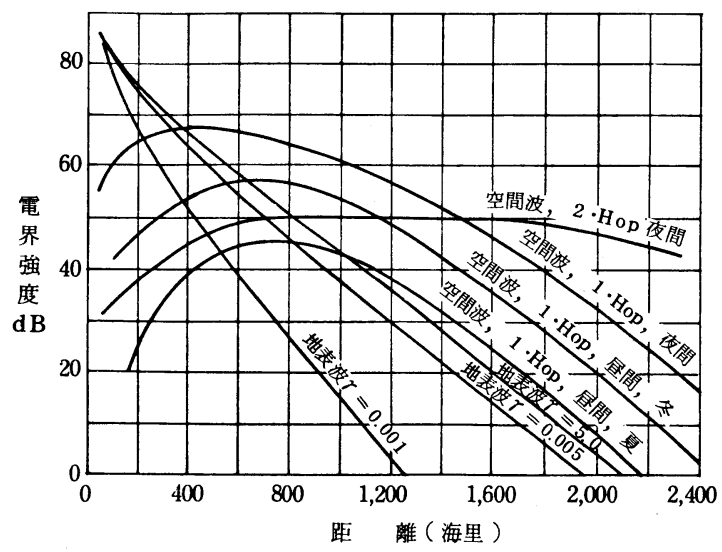

図 17 送信電力 $100 \mathrm{kw}$ の $100 \mathrm{kHz}$ 電波の距離に対 する電界強度 $(0 \mathrm{~dB}$ は $1 \mu \mathrm{V} / \mathrm{m}$ または大地導 電率 $r$ の $r=5 \mho / \mathrm{m}$ は海水, $r=0.005 \mho / \mathrm{m}$ は導電率の良い大地, $r=0.001 \mho / \mathrm{m}$ は同じ く悪い大地を示す.

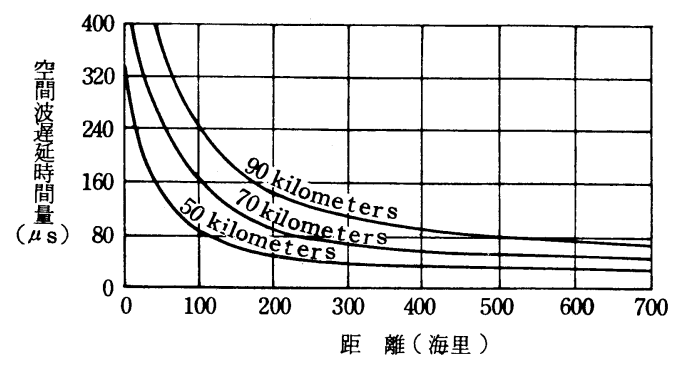

図 18 空間波の伝搬遅延時間 (パラメータは電離層の高さ)
夜間は $91 \mathrm{~km}$ として遅延時間を求めロラン表に記載され ている。

\section{4. デッカシステム}

デッカは長波の連続波を使う双曲線航法システムで英 国のデッカ社が開発し，政府の補助を得て同社が送信シ ステムの運用を行ない，受信装置は原則的にはレンタル 制である.わが国においてはデッカ社との契約にもとず き, 海上保安庁が北海道と九州に二つのチェーンを有し ており，今後次第に全国的に拡張してゆく計画のようで ある．世界的には英国および北欧を中心とするョーロッ パ沿岸, 南アフリカ南端, ペルシャ海, インド, オース トラリア, カナダ東岸からニューヨーク付近まで，およ び米西岸ロスアンゼルス付近にあわせて 30 数チェーンが 運用されている.

デッカシステムでは主局を中心に普通は色の名前をつ けた三つの従局, 紫, 赤, 緑を星形に配㯰するのが原則 であって，それらの局の区別は送信の周波数によってい る. すなわち，ある組局に対し基本となる周波数 $f(14.0$ 〜 $14.4 \mathrm{kHz}$ の間にほぼ $0.015 \mathrm{kHz}$ 間隔で）が割当られ ると, 各局は表 5 に示すようにその $f$ の $5,6,8,9$ と整 数倍の周波数で送信を各局がその位相関係を同期をとり つつ行なう.これらのコヒーレント (coherent)な（位 相の合った）各送信波は船上の受信機でそれぞれ受信さ れ, 図19の（b)に示すように受信機内で逓倍され, 主局 と各従局との最小公倍数の比較周波数で位相比較される. 位相の比較は従来はデュメ一タと称する電気一機械的な 回転式の位相差計によっていたが，最近は電子回路でそ れを行なう方法もできている．位相差測定のみによる距 離差測定であるので，当然，レーンごとに同じ位相差を もつアンビギティがあり，そのレーンの幅は基線上では 比較周波数の波長の $1 / 2$ で表のように比較的狭いので, 受信機は出港時にそのレーンを設定し, 以後は連続動作 によってそのレーン值をデコメータの回転数により保持 する要がある。

しかし，停電その他でこのレーン数の保持が不能にな

$$
\text { 表 } 5 \text { デッカシステムの特性 }
$$

\begin{tabular}{|c|c|c|c|c|}
\hline \multirow{2}{*}{ 項 } & \multirow{2}{*}{ 主 局 } & \multicolumn{2}{|c|}{ 従 } & 局 \\
\hline & & 紫 & 赤 & 緑 \\
\hline 送信周 波 数 & $6 f$ & $5 f$ & $8 f$ & $9 f$ \\
\hline 比較周 波 数 & & $30 f$ & $24 f$ & $18 f$ \\
\hline レーン幅（約） & & 0.2 海里 & 0.25 海里 & 0.3 海里 \\
\hline $\begin{array}{l}\mathrm{V} \text { 型の追加のレ } \\
\text { - 識別周波数 }\end{array}$ & $5 f$ & $8 f, 9 f$ & $9 f$ & $8 f$ \\
\hline $\begin{array}{l}\text { 1ソーン内のレーン } \\
\text { (レーン番号) }\end{array}$ & & $\begin{array}{c}30 \\
(50 \sim 79)\end{array}$ & $\begin{array}{c}24 \\
(0 \sim 23)\end{array}$ & $\begin{array}{c}18 \\
(30 \sim 47)\end{array}$ \\
\hline ゾーン幅（約） & & 5.8 海里 & 5.8海里 & 5.8 海里 \\
\hline $\begin{array}{l}\text { MP型のレーン } \\
\text { 識 }\end{array}$ & \multicolumn{4}{|c|}{$\begin{array}{l}\text { 各局がきめられた順序で } 1 \text { 局ずつ } 5 f, 6 f, 8 \\
f, 8.2 f \text { および } f f \text { 同時に送信する. }\end{array}$} \\
\hline
\end{tabular}




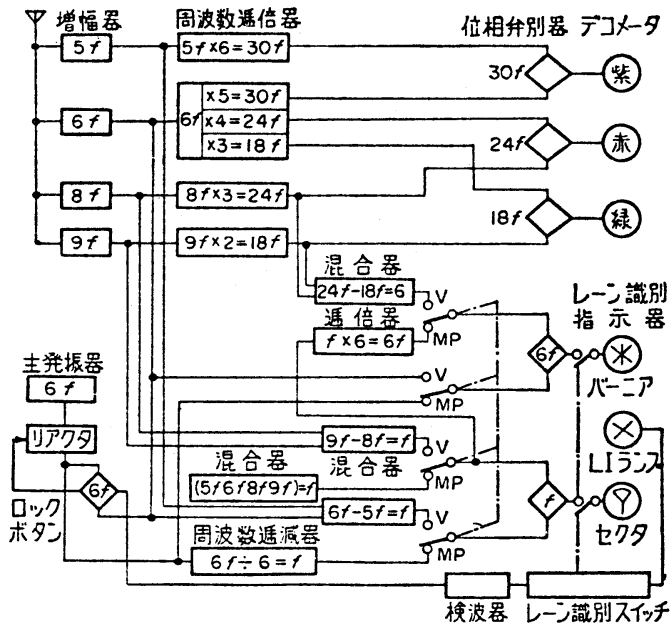

(a) 全ブロック図

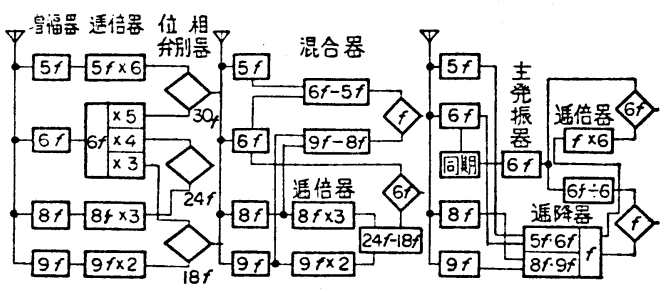

(b) 位相差測定時 (c) V 型レーン識別時 (d)MP型レーン識別時

図 19 デッカ受信機の構成
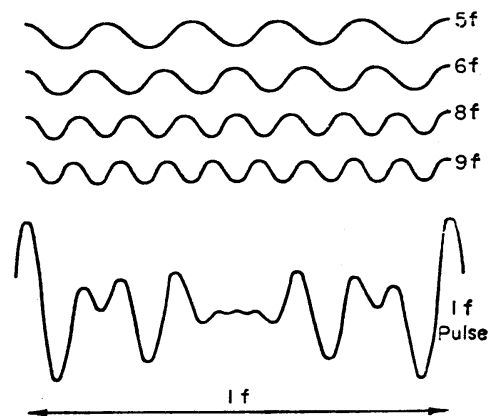

図 20 MP型レーン識別

ったとき，船がどのレーンにいるのかのアンビギティを 解く, いわゆるレーン識別という操作を要する. このた め, 各局は時分割で毎分 3 回の割でレーン識別用の送信 を行なう。このレー誡別にはV 型と MP 型(日本の局 はMPのみ）とがあり，V型では主局が $5 f$ と $6 f$ ，従局 が 1 局ずっ $8 f$ と $9 f$ 送信を行なって，受信機内で図 19 の (c)に示すように $1 f$ と 6 の信号をそれぞれ作って, この位相比較により, 比較周波数 $f$ の範囲内でのレーン の識別を行なう. $f$ の位相が繰返される幅をゾーンと呼 ぶと，その中にはいるレーンの数は表のように従局で異 なるが, ゾーンの幅は約 $10 \mathrm{~km}$ あるので別の例えば, 推
測航法などの方法で求める. MP (Multipulse) 型のレ 一ン識別は各局が 1 局ずつ順次位相関係の合った $5 f, 6$ $f, 8 f, 9 f$ の全周波数と送信し, 受信機内で図 20 に示 すように全周波数を合成して $1 f$ を作り，受信機内に記 憶した主局の $1 f, 6 f$ の位相と順次比較をするため, 4 周波数のうちの 1 ～ 2 の送信波の伝搬上の乱れがあって も影響が少ないという特徵がある.

デッカでは，このように送信波の位相測定によって各 局からの距離差を求めている. 各送信は 1 分間になん回 かの断続はするが，連続波的であるのでロランCのよう に地表波と空間波の分離ができず，空間波があるときは 地表波との合成位相となる．従って，デッカシステムは 原則として空間波の無い地域のみでしか利用不可能であ り，主局からおおむね昼間は $400 \sim 500 \mathrm{k} \mathrm{m}$ ，夜間は空 間波が強くなるので $200 \mathrm{~km}$ 程度までが確実に利用でき る区域と比較的狭いところでしか利用できない.

半面，相当に高い周波数での位相比較であるのでシス テム的な測位精度をもつことになる. 従って, デッカシ ステムでデッカ海図によらずに船位を求めるときは陸上 と海上，それに周波数による電波伝搬速度を分けて考え 次式によって双曲線を求める必要がある.

$$
C=m f\left\{\frac{\beta_{l}}{V_{l}}+\frac{\beta_{\omega}}{V_{\omega}}+\frac{D_{M l}}{V_{M}}-\frac{D_{S l}}{V_{l}}+\frac{D_{M \omega}-D_{S \omega}}{V_{\omega}}\right\}
$$

ここで $\beta_{l}, \beta_{\omega} \quad$ : 基線上の陸上と海上の距離

$D_{M l}, D_{M \omega}$ : 主局と受信点の間の陸上と海上の距離 $D_{S l}, D_{S \omega}$ : 従局と受信点の間の陸上と海上の距離 $m f \quad:$ 比較周波数

C : 総レーン数, 但し, 各従局の L O P に 対するレーン番号は表 5 に示す範囲の 値の繰返しとなる. 例えば, 緑チェー ンは 30〜37で 38はまた 30 にもどる.

$V_{M}$ : 主局電波の陸上伝搬速度

$V_{l}$ : 従局電波の陸上伝搬速度, 各従局ごと に異なる.

$V_{\omega} \quad$ : 各局の電波の海上伝搬速度

15. オメガシステム

ロランの生みの親である Harvard大学のJ.A. Pierce がロランCの非全世界性を解決すべく，より長波長の電 波を使う航法システムの開発と実験とを行なった結果， $40 \mathrm{kHz}$ を使う Radux-Omegaという実験システムでも, 全世界を覆うには約 30 局の送信局が必要という結論から, 更に波長の長い，電波としてはぎりぎりのところである $10.2 \mathrm{kHz}$ の超長波( VLF) を主として使用する航法シス テムを提案し，これを最終的なシステムであるという意 味でZに当るギリシャ語をとりオメガと名付けた.

オメガは運用に当っては 8 局の送信局で全世界をカバ 一する計画で現在建設が進められており，前述の 10.2 $\mathrm{kHz}$ のほか $11.33 \mathrm{kHz}, 13.6 \mathrm{kHz}$ などの周波数も併用し， 
送信局間の電波の識別はあらかじめ定められた順序と時 間に各局が約 1 秒ずつの送信を 10 秒ごとに繰返して行な うことになっている. 現在考えられているその順序を図 21 に示す. これらのタイミングは協定世界時 (UTC) ) 同期しているが，不連続性をなくすためうるう秒の補正 が行なわれていないので, 現在 3 秒遅れの毎 7 秒に $\mathrm{A} の$ セグメントがスタートしている.

$10.2 \mathrm{kHz}$ のほかに $13.6 \mathrm{kHz}$ と $11.33 \mathrm{kHz}$ を送信する のは, $13.6 \mathrm{kHz}$ と $10.2 \mathrm{kHz}$ 波の合成から $10.2 \mathrm{kHz}$ の 1 / 3 の $3.4 \mathrm{kHz}$ が，また， $11.33 \mathrm{kHz}$ と $10.2 \mathrm{kHz}$ からそ の更に $1 / 3$ の $1.13 \mathrm{kHz}$ 得られ，それらでの時間差測 定を絽返すことによって $1.13 \mathrm{kHz}$ の基線上でのレーン幅 が約 $135 \mathrm{~km}$ となり，レーン識別が実用上ほとんどの場合 完全に行なえるよう考えたためであり, 従って各送信局 はこれらの送信波の位相はすべて完全に制御し, コヒー レントになっている. 送信局は永い間, 北米ニューヨー ク, 南米トリニダッド, 八ワイ, ノールウェーの局で㬰 験運用が行なわれてきたが，北米はノースダコタの正規 の運用局に移り, 残り 3 局は増出力中であり, それにわ が国の海上保安汀が建設中の対島, アルゼンチン, 仏領 レュニオン島およびオーストラリアが順次開局され，全 8 局で正規の運用が行なわれる予定になっている.

これらの各局相互間の送信波の同期は他の双曲線航法 システムのように主局の信号を従局が受信をして同期を とるのでなく, 各局にそれぞれセシウムの原子周波数標 準を数台置いて，その平均的な周波数で制御が行なわれ るので, どの局が主局であるといった関係はない. しか し, 各局の信号のモ二タは行なわれ, 若干の調整は当然 行なわれる. $10 \mathrm{kHz}$ の電波に同調する空中線を作るこ とは実行上ほとんど不可能なので, できるだけ電波の放 射効率をよくするため高さ $450 \mathrm{~m}$ 程度の鉄塔を作るか, または地形を利用して山頂から山頂へわたした線から谷 へ導線を下ろす, いわゆるバレースパン形のアンテナを 使用している.

$10 \mathrm{kHz}$ といった低い周波数の電波は電離層の最下端の $\mathrm{D}$ 層を通り抜けることはできず，D層と地表面との空間 をちょうどレーダの電波が導波管という銅の管の中を通 るのと同じ形で伝搬をする. その状態を電界の変化で示 したのが図 22 で, 導波管と異なるのは電離層が磁気的完 全導体で反射係数が $R=-1$ であるという点である. 1 次

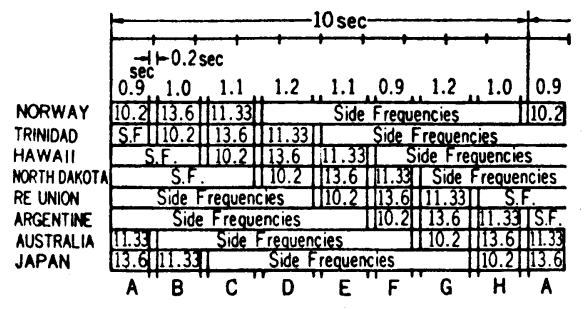

図 21 オメガ電波の送信順序

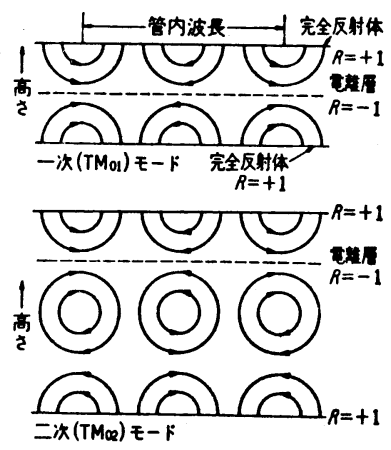

図 22 VLF電波の伝搬モード

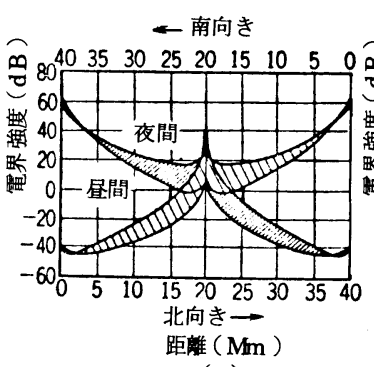

(a)

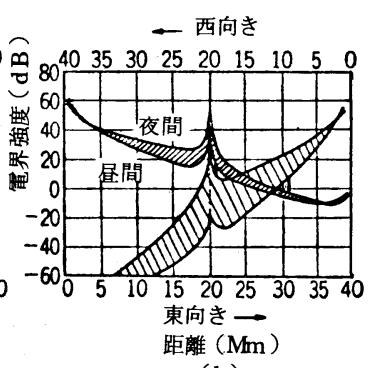

(b)
図 $2310.2 \mathrm{kHz}$ 波の层搬の減衰特性

と 2 次の両モードが存在するが, 2 次モードは減衰が早 く局から $1,000 \mathrm{~km}$ 離れると 1 次モードに対する影響は なくなる.このことは逆にオメガでは各送信局から約 $1,000 \mathrm{~km}$ 以内では, その局の電波の位相は 1 次と 2 次の 両モードの合成值であるので距離に比例した位相でなく なり正確な位置測定は不可能であることを意味する.

$10.2 \mathrm{kHz}$ 波がどの位の強さで伝わるかを示したのが図 23 の ( a ) ( b ) である. 赖軸は送信電力 $1 \mathrm{~kW}$ のときの電 界強度 ( $1 \mu \mathrm{V} / \mathrm{m}$ を $0 \mathrm{~dB}$ にとってある ), 横軸は送信局

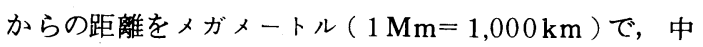
央の $20 \mathrm{Mm}$ はちちど地球の裏側に当る.なお, この図 は北極地方などでの異常な減衰は含まれていない（a） 図は地球の磁界に添った南北方向の伝搬で普通は夜間と 昼間の值となる.この場合は南から北への伝搬と北から 南への伝搬は対称的である. 中央付近にある綎線は 10 $\mathrm{dB}$ の線で, 南北反対向きの両方の伝搬波の干渉がこの線 より狭いところでは位置測定に影響することを示してい る. (b) 図は地磁気の水平成分に直角な赤道付近での東 西方向の伝搬で, 伝搬方向により大きな非対称のあるこ とを示す．細かいハッチは東向きの伝搬で荒いハッチの 西向きの伝搬に比べその減衰が半分以下である. これら の図から送信電力 $1 \mathrm{~kW}$ のオメガ送信局は地球の裏側の 径数百 $\mathrm{km}$ の部分を除き, ほぼ地球面全体で利用可能で あることを示している.

図 24 は $10.2 \mathrm{kHz}$ の電波の伝搬の位相速度が電離層の 高さで変化することを示している. D層の高さは普通昼 


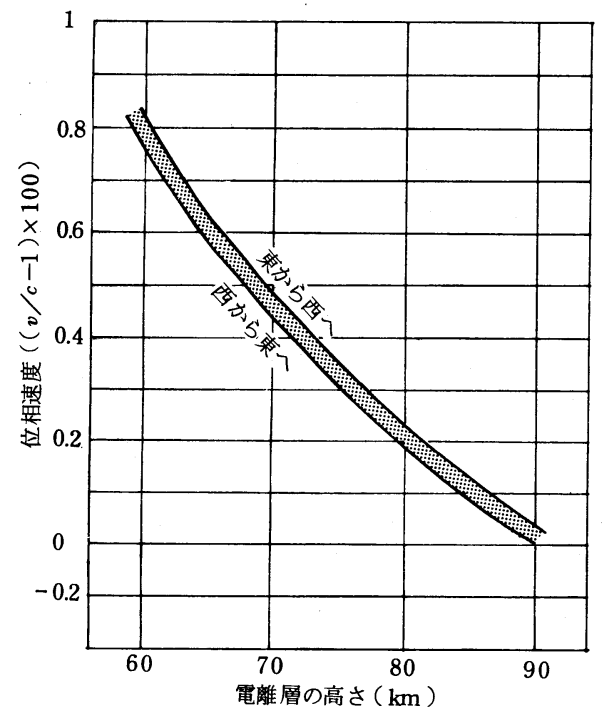

図 $2410.2 \mathrm{kHz}$ 波の位相速度

間は約 $70 \mathrm{~km}$, 夜間は約 $90 \mathrm{~km}$ であるから昼間のほうが 電波が速く伝搬することを示している. 従って，オメが 送信局から受信点までの間の地域が昼か夜か，または昼 の部分がどの位であるかによって電波の伝わる速さが変 化し，その補正をしないと伝搬時間を距離に正確に換算 できない。位相速度は，また地表面の導電率によっても 変化する.

オメガの $10.2 \mathrm{kHz}$ の位置の線の番号は次式によって つけられている.すなわち，LOPの番号を $L$ とすると， $L=\left(D_{m}-D_{n}\right) \times(10,200 / 300,574)+900 \quad$ (7) ここで $D_{m}, D_{n}$ はそれぞれの局までの距離であり $(10,200$ $/ 300,574)$ は $(f / c)=(\omega / 2 \pi)$ を示している. この $L$ の值に対する伝搬時間の前述の電離層高による補正は あらかじめ計算され, 空間波補正表 (Skywave Correction Table, SWC)として発行されている.これ は各局ごとに地球上の緯度と経度の $4^{\circ}$ ごとに季節変化を 半月ごとにとり，世界標準時の 1 時間ごとにセンチレー ン単位（レーンの $1 / 100)$ で示されている. 従って, オ メガ受信機で求めた位置の線の值は小数点以下 2 桁を含 む6桁で表示されているが，この小数点 2 桁目にそれぞ れの局の補正值を単純に加減すればよいが, より正確に するには補正表の值の隣の数字との補間を要する.

このようにオメガの測定值は $1 / 100$ レーン（基線上 でほぼ $150 \mathrm{~m}$ ) まで得られるが，その測位精度を左右す る主因はこの SWC 表の精度とその適用にかかっている といえる. その問題点はつぎのとおりである.

（1） SWC 表の予測計算の方法および使用の各パラメ ータが正しいかどうか.

（2）日々の電離層の変化がどの程度あるか.

（3）太陽活動の異常による異常伝搬の影響など.

この中で (1) はオメガ局の長期の実験運用がこの表の
評価に重点が置かれているので，今後も年々その精度が 向上されていくことが期待される.（2）の変化はかなり の值 $(10$ ２0センチレーン）にのぼることがあり，これ がオメガの測位精度に主として影響し，現在までの評価 ではオメガの測位精度は昼間 1 海里, 夜間および薄明 2 海里といわれている. これ以上のその改善は日々刻々の 電波伝搬状況をモ二タし，そのモ二タ局から数百 $\mathrm{km}$ 学 範囲の船にリアルタイムの補正值を放送するデファレン シャルオメガという方式をとらなければならないだろう. (3)についてはまだ十分の資料はないが，主として極を 横断してくる電波と高緯度での受信の際が問題となり, 太陽の黒点活動などに伴なう電離層のじょう乱に原因が ある. その種類をあげると, 電離層突然じょう乱 (Sudden Ionospheric Disturbance, S I D)，極冠じょう乱 (Polar Cap Dist urbance, PCD ), 極光じょう乱 (Auroral Zone Disturbance, AZD)，オーロ ヒスなどがあり ご これらの発生やその大きさは今のとこ ろ予測困難で, その結果は異常な船位誤差や測位不能, 連続受信の中断などの原因となる. 現象の大略を述べる と S I Dは太陽 フレアからのX線により電離層の高さが急 に下がるためで, 昼間に生じ位相の進みが数分ないし数 十分続く. 大きなものは年十数回, 中小規模なものは再 々発生する. PCD は太陽からのプロトンの放射で極地 方の下部電離層に異常電離が生じ, 数日あるいは数十日 と長く続くとともに磁気フレアによる短時間の A Z D, 高緯度地方でのオーロラヒスによる異常雑音で数分ない し数十分の受信中断を伴うことも多い.

オメガの受信装置は各局の信号を受信し, 装置内部で 作られたゲート信号によって図 $21 に$ 示した各セグメント の信号を分離して, 装置内の水晶発振器からの信号をも とにして各局の受信信号の位相に追尾した信号を作って， それらの信号間の比較から位相差を測定する. その位相 差はデジタル表示するほか，アナログ記録器によって， フルスケール 1 レーンの記録をする．位相比較方式であ るため, 出港後は連続動作によってレーンの值をデジタ ル表示で保持し，七ンチレーンが99から0に変化すると きはレーンの值に 1 を, その逆のときにはー 1 を加える ことになるが，そのミスカウント(これをレーンスリッ プという)を生ずることが絶無でないためにアナログ記 録の調査でそれを発見する. 3 周波数は普通切換受信す るが，同時 $2 \sim 3$ 周波の受信可能な装置もある. また， 受信信号の位相の追尾は普通は 4 局について行ない 2 本 のLOPのレーン值を表示するが同時 3-L OP表示ので きる装置もある.

受信装置からの L O P のレーン値を電子計算機に取り 込めば自動的に船位を求めることができるのは他の双曲 線航法システムでも同様である. その方法の概略を述べ るとつぎのとおりになる.

（1）各送信局の位置の緯度 - 経度, 受信点の推測位置 （緯度・経度 ），測定 L O P の值を入力する. 
（2）推測位置と各送信局との距離（例えば（2)式より） を求め $(7)$ 式（オメガのとき，その他のシステムもそれ ぞれの項に示してある )からLOP の值を求め，また推 測位置から微小単位距離緯度方向または経度方向に移動 したところでのLOP の值も求める.

（3）推測位置のL OP と測定 L O P の值を比較し，そ の差を求めると, それが微小単位距離ずらせたことによ るLOP の変化值（偏微係数に相当）を係数とし, 緯度 差, 経度差を末知数とする方程式が作れる.この方程式 は 2 本の LOP についてそれぞれできるから 2 元 1 次方 程式が二つでき，緯度差，経度差が求まる。

（4）その差值を加えた新推測位置を求め緯度差, 経度 差が一定の微小值まで収束するまで以上の計算を繰返す.

こうして位置を求めるときに，オメガでは SWC の值 をどゔ取り入れるかが最も問題になる．表を計算するこ とは小型計算機では無理であり，また，表をメモリする にもメモリ容量の問題があるので，それを折中した簡易 計算方法がいろいろ検討されている ${ }^{10)}$.

\section{6. 双曲線航法システムの船位誤差}

双曲線航法システムで時間差測定に例えば $1 \mu \mathrm{s}$ の誤差 があると，それがどのように測位䛊差になるかについては，

（1）船位が基線から離れると双曲線が開き，位置の線 の誤差が大きくなる.

（2）位置の線の交角によって誤差平行四辺形あるいは 誤差棈円が細長くなる

と二つに分けて考える必要がある.

前者については図 25 に示すとおり，双曲線では任意の 点 $\mathrm{P}$ における双曲線の間隔 $S$ は $S=a \operatorname{cosec}(\varphi / 2) こ$ こで， $a$ : 基線上の双曲線の間隔， $\varphi$ : $\mathrm{P}$ 点から見た $\mathrm{A}$ $\mathrm{B}$ の夾角，という関係があり，時間差測定誤差を $\Delta t(\mu$ $\mathrm{s})$ とする, 位置の線の誤差 $\Delta s$ (海里) は,

$$
\Delta s=0.081 \Delta t \operatorname{cosec}(\varphi / 2)
$$

になる．夾角一定ということから図の $a, b, c$ の各円の 上では同じ位置の線の誤差となり，また，基線上では $\varphi$ $=180^{\circ}$ であるから $\Delta s=0.081 \Delta t$ となる. 更に基線の両 延長線上では $\varphi=0$ であるから $\operatorname{cosec}(\varphi / 2)$ は無限大 となり誤差は理論的には無限大になり，測位はできない. 双曲線航法システムでは基線が長いと双曲線の開きが少

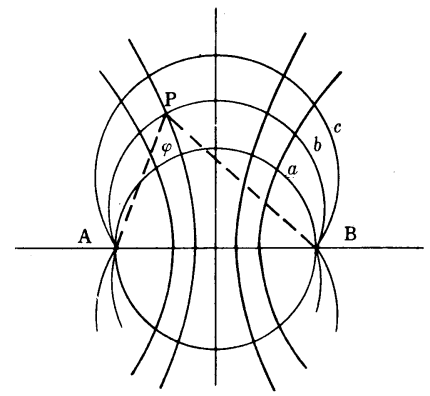

図 25 双曲線上の夾角
なくなるという有利さがあり，オメガのような長基線の システムの一つの特長となる。

2 本の位置の線の交角による船位測定誤差については, 紙数の関係上結果のみを示すと，図 26 のように A 局が両 組局に共通なような局群では， A B 組局での夾角を $\varphi_{1}$, $\mathrm{AC}$ のそれを $\varphi_{2}$ とすると，位置の線の交角 $\theta$ は，

$$
\theta=\left(\varphi_{1}+\varphi_{2}\right) / 2
$$

となり,ここでは確率密度でその位置決定誤差を与えると,

$$
K=\frac{0.0724}{r_{1} \cdot r_{2}} \sin \left\{\left(\varphi_{1}+\varphi_{2}\right) / 2\right\}
$$

となる.ここで $r_{1}$ と $r_{2}$ はそれぞれの組局での夾角 $\varphi_{1}$ と $\varphi_{2}$ に対するそれぞれの位置の線の確率誤差である (図 6 ). 一例として, この式を用いて求めた基線角が $120^{\circ}$ の 2 組 局の船位誤差の確率密度の分布を図 27 に示す.

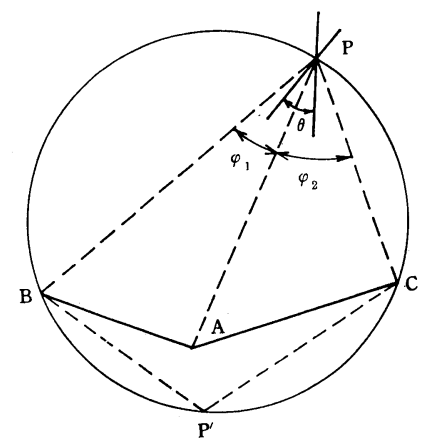

図 26 双曲線の交角

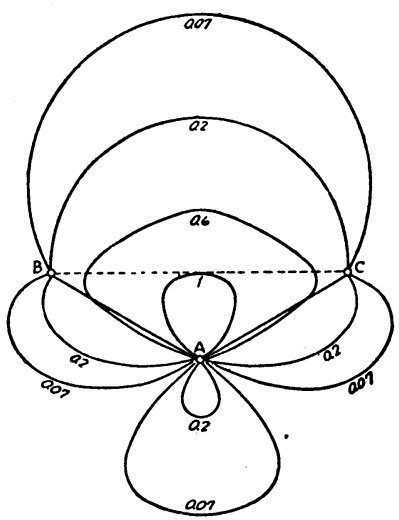

図 27 双曲線航法の測位精度の確率密度 分布例

\section{文献}

8) C. E. Potts \& B. Wieder : Precise Time and Frequency Dissemination via the Loran-C System, Proc, of IEEE, 60,5 , p. 539 (1972)

9）羽倉幸雄：オメガ航法のじょう乱問題，電波時報 $26 ， 3, p$. 58 (昭 48 )

10）例えば，関根兆五ほか：ハイブリッド自動航法装置，日本無 線技報No. 7 p. 6 （1973） 